\title{
The Effect of Financial Fraud on Commercial Banks Performance Case Study of Equity Bank Rwanda Plc.
}

\author{
Andrew BARIYO' ${ }^{1}$, Claud RUSIBANA ${ }^{2}$ \\ ${ }^{1,2}$ Mount Kenya University \\ DOI: 10.29322/IJSRP.11.10.2021.p11850 \\ http://dx.doi.org/10.29322/IJSRP.11.10.2021.p11850
}

\begin{abstract}
Fraud is like an epidemic disease that affects banking sector and has great effects on the country's economy. This causes decline in liquidity of commercial banks hence performance depreciation. Therefore, the study identified the effects of financial fraud on financial performance of commercial banks in Rwanda taking a case of Equity Bank Rwanda Plc. Specifically, the study sought to assess the effects of fraudulent loans, fraudulent invoices and identity theft on bank performance. Descriptive and correlation research designs were utilized in the study. Population of 100 respondents from different Kigali branches was selected which majorly composed of the managers, tellers, credits and risk officers and finance officers. The study utilized primary data collected using questionnaires and secondary data sourced from Equity Bank Rwanda reports and National Bank of Rwanda. Data was analyzed using IBM SPSS version 21 and presentation done in figures and tables. From correlation findings, Pearson correlation coefficient of -.690, -.630 and .650 for fraudulent loans, fraudulent invoices and identity theft respectively was found. This implies that as financial fraud cases increases, commercial banks performance reduces. The $\mathrm{R}$ squared value was $62.4 \%$ and $\mathrm{F}$ statistic was 53.09 in the regression analysis. Additionally, the beta coefficients for fraudulent loans, fraudulent invoices and identity theft were $-0.151,-0.582$ and -0.431 respectively with respective significance values of 0.039 for fraudulent loans and 0.000 for both fraudulent invoices and identity theft. The study concluded that financial fraud particularly fraudulent loans, fraudulent invoices and identity theft have significant negative effect on bank performance. The recommendation of this study includes commercial banks putting in place fraud detection mechanisms and strengthen risk department to ensure that potential fraud risks are detected on time to avoid their occurrence. Additionally, the study recommends appropriate scrutiny of loan applicants documents to ensure they are true documents. Lastly the study recommends strict adherence to fraud control mechanisms in place within and outside the bank.
\end{abstract}

Keywords: Commercial Banks, Fraud, Financial Fraud, Performance

\section{INTRODUCTION}

Globally, banks are considered profitable financial enterprises by majority due to their large number of customers, high customer retention and profit growth. Despite all these, just like any other business venture, commercial banks are faced with serious challenges that often slow their business including political issues, competition, the market forces of demand versus supply, poor management and fraud.

In the East African region, Central Bank of Kenya report indicated that fraud was the major challenge that led banks like Dubai bank to collapse. Several others were put under receivership which included Imperial Bank and Chase Bank. This triggered the government to provide guidelines and restrictions with an aim of preventing money laundering, which included ensuring all deposits and withdrawals transactions that exceeded a certain amount were explained. In the past a customer could walk transact large amounts of money without questions being asked.

According to Idolor (2010), there exist rapid rise in fraud rate in the banks that is making many stakeholders in the banking sector to lose bank confidence and trust. He further explains that fraud in the banks mostly occur easily when there is an insider facilitating and collaborating with the external fraudsters. It is therefore important to ensure that all the staff in the banking sector did their duties with highest sincerity and responsibility without of any element of fraud. This will build trust and good will from the public.

Kimani, (2011), asserts that fraud, in the banking sector decreases organizational assets and greatly increases the banks liabilities which also raises issues of confidence in the public, affects bank status and can result to bank failure and closure. Experts and academicians believe that fraud breaks the credibility and the foundation of banks across the world therefore causing high levels of distress. This study is faced with a problem of revealing how fraud generally affects the effective performance of banks in Rwanda considering the effects in the economy.

Various studies have been carried out and show that effective risk management in the banking sector is increasingly becoming an important element that enhances the growth and sustainability of commercial banks. Issues involving currency management indirectly affects a nation's economic system. Since commercial institutions hold huge amounts of deposits as compared to other non- commercial, 
financial or banking institutions, currency management therefore impacts the operations and performance of the entire banking sector and also the country's economy in general. In modern period, fraud issues have become a common issue especially in cases where some banking institutions across the world have been negatively affected, resulting to huge losses. For instance, the debt crisis that was experienced in the year 2011/2012 heavily affected the European Union banking sector and also the economy. This crisis reflected that weaknesses in the commercial banks' internal controls, particularly on matters that relate to fraud, can have serious effects on banks' sustainability resulting to instability in financial sector affecting economy of different countries (Vadoodparast \& Hamdan, 2015).

According to Miller (2006), bank profitability and success result from well-formed policies and execution when it comes to monetary matters. These results are evident when it comes to the bank's investment returns and other performance measures. This ultimately provides the financial gain or profit.

\section{Problem Statement}

Effect of financial fraud are a major issue in the commercial Banks across the world. In modern period, many customers depend on internet banking for all their banking needs. This has intensified and drastically increased online transactions. According to Cuevas and Fischer (2006), online banking is characterized by non-physical presence of customers to confirm financial transactions. As a result, fraudsters have taken advantage since internet offers higher opportunity for online theft from the innocent customers. According to Kimani (2011), criminals usually organize themselves and even support each in the fraud by forming an organized online network.

Fraudsters are usually interested in stealing details that enable them access the bank account of customers, including an email from credible appearing source asking critical information like passwords and usernames a practiced called phishing. This practice has threatened online security as credit cards have also become very popular and a common payment mode (Bergholz et al.,2010). Although it's hard to ascertain frequency of card fraud due to the issues affecting tracing of fraud within the banks and the fact that not all customers report fraud, it is estimated that that card fraud alone exceeded $\$ 10$ billion in the year 2009 (ACI Payment Systems, 2009). Its therefore worth noting that fraud whether it is offline or online it greatly affects commercial banks and their operating performance which leads to increased costs (Gates\&Jacob, 2009).

The cost of fraud is huge, for instance it is believed that 5\% of the world's GDP which is equivalents to2.6 trillion dollars is paid in bribes every year. Referring to 2018 Global Economic Crime and Fraud Survey, 47\% of Rwandan respondents, reported to have had an experience of not less than one form of economic crime in the 24 months that was covered by the survey. The report indicated that the figure was lower than global average which was $49 \%$ and also the African average cases which were at $62 \%$. Fraud has caused banks huge amounts of losses and has also lowered their levels of profitability and performance. According to the Rwandan Banker release of August 2015, the region, there were more than $\$ 245$ million related cyber loss that was reported in the regional financial industry in the year 2014, there were more than $\$ 300$ billion cases of cyber loss that were reported worldwide in that year. Rwanda specifically reported a loss of Rwf 257 million loss in 2014 and through bank fraud. This reflected need to address internal security issues and breaches to support the sector. In the beginning of the first quarter of 2015, Rwanda recorded a loss of about 174 million through bank fraud. The cost of fraud stretches deeper resulting to reputational effects, financial effects, and psychological effects. As a result of this problem the researcher was interested in investigating bank financial fraud and performance.

\section{Objectives of the Study}

i. To assess the effect of fraudulent loans on commercial banks financial performance.

ii. $\quad$ To determine the effect of fraudulent invoices on commercial banks financial performance.

iii. To determine the effect of identity theft on commercial banks financial performance.

\section{REVIEW OF RELATED LITERATURE}

\section{Overview of Commercial Banks}

Ball (2009), explains that the recent common cases of fraud in the banking sector is posing a great challenge in the sector and a solution need to be provided as huge amounts of monies that are involve are at risk which further results to adverse implications on the economy of a country. In this paper performance was measured in terms of profitability and particularly return on investment.

Githecha (2013), a bank is a space for disbursement of various funds which include: processing of credits and lending functions to various clients and also accepting deposits and extending advances of funds. It is mandated by a state provide different financial operations including granting loans, keeping safe boxes, precious valuables, provides business consultancy and trusteeship services, it also plays a role financial agency among other roles. 
According to Njenga and Osiemo (2013), Security in Banks has increasingly become a critical issue in the modern banking sector. In the last few years several cases of fraudulent cases have been reported to have been reported by third parties and the trend has been on an upward trend. As a result, the prevention of fraud has become an important area of concern to banks, to the customers and also the public policy makers.

Hoffmann and Birnbrich (2012), in their research they explain that the management and acceptance of financial fraud is a common practice in the business of banking. In order for banks to maintain their liquidity so that they are able to serve their customers demands in terms of loans and play community role successfully, they have to accept deposits, invest in securities and accept deposits with varied maturity periods and interests. Consequently, banks earnings and capitals are exposed to varied interests rate movements. Additionally, due to changes in the competitive environment in the banking sector, the need for prudent fraud risk management cannot be ignored.

Fraud in the banking sector affects not only the banks but also customers. This means that the bank incur high levels of operational costs when they have to refund their customers their money lost through fraud while on the other hand the customer experiences emotional and time loss as they have to first detect the transaction that was fraudulent, report the incidence which in many banks is a process that will require reissuance and or reopening of account or the card that had compromised, the process often requires launching a dispute to initiate a possible reimbursement (Kimani, 2011).

According to Njenga and Osiemo (2013), when a customer becomes a victim of bank fraud they get affected and this affects their perception and the sense of being secure in that bank thereby compromising the bank customer relationship due to lack of confidence with the bank.

\section{Types of Fraud}

\section{Fraudulent loans}

Among the traditional functions of financial institutions is to offer loans and other credit facilities to the customers. In this process of extending credit to the customer, possibilities of fraud occurrence are evident. The fraud may occur in any stage right from the first interaction between the customers and the bank agents and the final receipt of loan by the customer. In the process of credit extension, fraud may occur at any stage, from the first interaction between the customer and the bank to the final payment of the loan (Abolade $\&$ Olusola, 2020). Fraudulent loan occurs when credit is granted to a non-borrower customer or to a customer who exceeds his or her credit limit. The fraud dimension of this act is the intention to conceal the deal to the head office staff on routine basis to deceive with forged statements and documents. At advanced levels of credit fraud, perpetrators apply for approval of credit facility of another customer who is unrelated with the first customer. Meaning a credit facility for customer ' $\mathrm{X}$ ' to be drawn is diverted for use of customer ' $\mathrm{Y}$ '. Fraudulent loans have been found to significantly relate to bank performance since bank sometimes take the burden of fraudulent loans if the fault is on its. This reduces profitability of the bank. Additionally, frequent occurrence of fraudulent loans scares away customers in that particular bank affecting its interest earnings on loans and profitability (Owolabi, 2010)

\section{Identity Theft}

According to Chiezey \& Onu (2013) identity theft involves use of other people's identity information in order to access his or her finances and conduct unauthorized purchases. This information may be gotten from credit cards, debit cards and national identity cards. Access to a person's ID number, credit and debit card numbers and PIN can enable successful completion of a transaction on someone's name. Lai et al (2012) stated that identity theft is one of the cyber security threats that makes individuals to develop fear or minimal willingness to engage in e business. This is because of the fear of stealing of identity information hence cash fraud may occur. A study by Abdul and Bode (2020) in Ghana did indicate that online identity theft greatly influences customer's willingness to engage in ebanking transactions. Customers have fear that their identity information can be access by someone else and get fraud of their accounts. Its therefore important that businesses develop proper ways to curb identity theft in order to create confidence among their customers (Fernandes et al., 2014).

\section{Fraudulent invoices and Payments}

Invoice fraud involves fake invoices being sent to the company as a request for payment or presented to the bank for payment processing. The information in fake invoices are always altered in order to benefit a particular person conducting the fraud. Employees in the banking sector can also collude with customers to conduct invoice fraud for a certain company. They can withdraw the funds from the company's account by setting up frau vendors in accounts payable and pay fake invoices since they have all the details of the company in the system. Alternatively, bank employees can switch account numbers in online bill pay system and utilize company finances for various payments. According to Musoke (2008) some employees use software to obtain blank cheque and insert their name in to the payee line. Additionally, they submit fake receipts on draft report for expenses or they deposit company cheques into their personal accounts. 
ACFE (2009), Kingsely (2012) and Akinyomi (2012) also stated that staff can collude to defraud an organization of its assets such as cash, inventory and customer information. banks should therefore take keen interest of the security of its assets by ascertaining the location, and responsible employee for the assets. Therefore, banks must take into consideration the location, place and security of assets and the responsible employees for the assets. According to Kingsley (2012) studies the common employee frauds involves paying for non-existent goods, presentation and payment of inflated invoices and unlawful acquisition of property information.

\section{Unauthorized Bank Withdrawals}

Miller (2006), explains that unauthorized bank withdrawal is a situation where someone manages to access and withdraw money from another person's account without their direct authority. This can take a form of someone forging another person's details including the signature and withdrawing the money from the bank counter and it can also take the form of a fraudster accessing person's identification number(PIN)details then using it to withdraw money from the Automatic Teller Machines(ATM).

According to Kanu and Okorafor (2013), who carried a research to examine the nature, the extent and even looked at the effect of fraud on commercial Banks deposits in Nigeria. Their main objective was to establish the amounts of moneys that are involved in fraud. After collecting the quarterly fraud case reports from Nigerian Banks between the period of 1993 and 2010 they established that the most common type of fraud in Nigeria Banking sector is withdrawals that are fraudulent.

\section{Fraudulent Money Transfer}

Akinyomi (2012), from his research on fraud in Nigeria banking sector and its prevention, he established that fraud cash transfer is a situation where a criminal or fraudster gets a fraudulent request and changes a legal fund transfer consciously with a purpose of committing the fraud. The criminal then collaborates with another fraudulent staff in that Bank to access the money from fraud.

\section{Causes of Fraud}

Various reasons have been argued to explain why people resort to committing the crime of fraud when they are in an enabling environment. Kanu and Okorafor (2013), established that most common fraud causes can be classified into: Management, Technological, Social, Legal and personal causes.

\section{Technological Causes of Fraud}

According to Kanu and Okorafor (2013), who carried a study and identified technological causes of fraud. Their study established that as a result the advancement of technology in the world, where nearly everything has been computerized. The fact that the world has become a global village and people can communicate easily when they are very far like when they are near has facilitated fraudster crimes. This also means that fraud cases can happen very quickly and without being noticed and it can be executed by fraudster who is not necessary near. The technological related frauds include Electronic Fund Transfers, Spams Emails and ATM frauds. They further explained that technology is advancing every day and so are argued related cases.

\section{Legal Causes of Fraud}

According to Kanu and Okorafor (2013), their study classified the legal causes of fraud that particularly happen because of the process and nature of legal justices. In most cases, the nature of fraud cases usually takes a prolonged period to investigate them exhaustively. This means that the fraud criminal can easily commit fraud and relocate without them being arrested. It is also believed that judiciary systems can be compromised this means that the police officers, the prosecutors or even the judges can be corrupted and thereby the fraudster gets away easily. In addition, those arrested with fraud can easily bail themselves out and thereby get their freedom.

\section{Behavioral Causes of Fraud}

Adepoju (2010), study established that the personal causes of fraud involve fraudsters who are professional criminals. This means that they have specialized and perfected on how to defraud different organizations including banks. These criminals move from one bank to another with the objective of committing fraud. In their plan, they ensure they make friends with the staff working in the bank in order to facilitate them to commit the crime. The personal case can be due to poor upbringing where some parents fail to inculcate expected moral values in their children and others due to various reasons, leave the role of parenting to the teachers or the society. This behavior can also be as a result of poor choice of mentors or friends. According to Kanu and Okorafor, (2013), they argued that the social cause is attributed mostly by the values and expected norms in the society; however, due to the need to acquire them, people engage in fraud. A good example is the society respects those who have acquired wealth and irrespective of the source.

\section{Management Causes of Frauds}


According to Kanu and Okorafor, (2013), the management cause of fraud is as a result of the management and those in positions to make decisions in bank inactions or actions and consequently their failure to take actions or the actions that they take results to fraud. This involves different sectors including staffing whereby the banks are expected to take comprehensive background check of the individuals they are hiring.

The management is expected to undertake a background check of potential employees from former learning institutions and employers. The banks and other employers may place a lot of emphasis on grades and academic qualifications thereby leading to certificates manipulations. In addition, poor working conditions that include low remunerations can result to fraud particularly in the banks since they are that are believed to make high profits. Erickson et al (2006) research shows that it is risky to have weak internal controls by use of inexperienced or incompetent members of staff or even over depending on few employees as this also contributes to bank fraud.

\section{Empirical Literature}

Shaher, Kasawneh \& Salem, (2011), researched on the major factors that affects banks' performances in Middle Eastern Countries using Principal Component Analysis technique using 23 variables. The findings indicated that the six variables had a commonality index of above 0.5 with the highest commonality index being 0.852 and least being 0.529 . The study findings identified six variables which were important factors that affect bank performance including bank characteristics, competition, economic Indicators, regulation, legal environment and Country risk. Bank characteristic was found to have the greatest effect while country risk had the least effect. The study recommended that banks need to concentrate on six identified factors by banks more particularly bank characteristics to grow towards global standards.

A study was conducted by Meiryani et al (2020) in Indonesia to determine the effect of financial target and stability on fraudulent financial statements. The study utilized secondary data from Indonesia stock exchange and companies were chosen purposively. Regression model was used to attain the research objective. The results did indicate regression coefficient of 9.90 with $\mathrm{p}$ value of 0.0015 for financial target. Additionally, the results indicated a regression coefficient of -0.83 and $p$ value of 0.389 for financial stability. The study concluded that financial target has a significant effect on fraudulent financial statements whereas financial stability had insignificant effects. The recommendations for the study included strengthening of internal control systems and employing competent auditors and accountants to minimize fraudulent practices hence achievement of financial targets.

Ashu and Bindu (2009) conducted a study in India to investigate reasons for bank frauds and implementation of preventive security controls in the banking sector. the study adopted both descriptive and inferential statistics to achieve its objectives. Descriptive statistics did indicate that $68.77 \%$ of respondents supported lack of training and low compliance level of employees as main causes of fraud. Additionally, $68 \%$ of respondents cited staff overburden and competition among banks while $65 \%$ cited corruption among bank employees as the causes of bank fraud. The study concluded the above factors as the main causes of fraud in the banking sector in Indian banks. The study recommended that proper training and strengthening of internal control systems within the banking sector to avoid fraudulent practices occurrence.

According to, Bhasin (2007), research on the magnitude and causes of cheque fraud in India and he found that weak internal control systems and corruption among employees had a rating of 4 in a scale of 1-5 which meant that weak internal control systems and corruption were the main causes of cheque fraud. The recommendation for the study was that there is need for professional auditors to be integrated in examining of the new technology plus the technology applications to enhance security matters.

Charan S. (2016) investigated frauds in the banking sector in India using secondary data and interview approach. Data was collected from all the players in the banking industry reporting financial misconducts. The results indicated that Private banks led in number of total cases of frauds with $55.16 \%$ while nationalized banks led in number of fraud cases arising from loan advances with $65 \%$. These results did indicate that there is widespread occurrence of frauds in the banking industry in India. The study recommended establishment independent specialized cadre in financial matters by government to conduct investigations and report on time. Additionally, use of current technology which enhances financial security by banks in addition to adoption of stringent punitive laws meant to curb fraudulent practices should be practiced.

In Pakistan, various tools are used by banks to manage foreign currency frauds including portfolio diversification, assets and liabilities matches and use of currency derivatives mainly swaps, options and contracts. The most popular derivative used by commercial banks is forward exchange contracts, followed by currency swaps and least used is currency exchange options. Additionally, the use of derivatives depends on bank size and ownership and level of exposure of the bank to foreign currency relative to net assets. However, exchange rate volatility and bank type does not in any way influence use of derivatives (Sabri,2011).

Okoye and Gbegi (2013), conducted a research on the effects of fraud and related crimes on Nigerian economic performance using secondary data. The study utilized regression model to achieve its objective. The regression findings revealed $p$ value of 0.023 . this indicates that fraud and other financial crimes had significant effect on Nigerian economy. The study recommended training of Auditors 
ISSN 2250-3153

and accountants on forensic audit investigations. Also the study recommended that internal control systems be strengthened to minimize cases of fraud.

Wamboi and Gitahi (2016) conducted a study in Kenya to determine the effect of fraud on performance of commercial banks in Kenya using descriptive research design and 11 Tier 1 banks. The study findings revealed that the regression coefficients for fraudulent cheques, fraudulent invoices, fraudulent loans and money laundering to be $40.7 \%, 17.2 \%$ and $6.5 \%$ and $54.4 \%$ respectively with corresponding $\mathrm{P}$ values of $0.000,0.003,0.001$ and 0.0001 . The study concluded that all the four types of financial frauds had significant effect on financial performance of commercial banks. The study recommended setting up of fraud detection mechanisms in commercial banks such creating a department for fraud detection to handle fraud cases and advice accordingly. Additionally, liquidity ratios should be taken to account to ensure that available liquid assets are able to meet short term financial obligations thereby shielding the banks from financial distress.

Independent Variable

Financial Fraud

- Fraudulent Loans

- Fraudulent Invoices

- Identity theft

\section{Dependent Variable}

$\longrightarrow$\begin{tabular}{ll|} 
Bank Performance \\
$\bullet \quad$ Bank Profitability \\
$\bullet \quad$ ROI
\end{tabular}

\section{Moderating variable}

- NBR'S regulations and policies

- Exchange rate Fluctuations

- Inflation rate

Figure 1: Conceptual Framework

\section{RESEARCH METHODOLOGY}

This study made use of descriptive and correlational research designs. The study approach was mainly quantitative where numerical data was used to achieve the research objectives.

\section{Population and sampling}

The target population was 100 respondents from Equity Bank Rwanda Plc. branches in Kigali city. The respondents comprised of Head of Departments, branch Managers Operations Managers and Customer care/Front desk officers.

Stratified random sampling was adopted in selecting respondents. The employees were grouped into various strata according to departments and management levels. Particularly this study targeted managers, tellers, finance officers and risk and credit officers which formed various strata and therefore use of stratified random sampling was most appropriate.

\section{Data Collection Methods}

This study utilized both primary and secondary data in order to effectively analyze financial fraud and Commercial Bank performance. Questionnaires containing closed ended questions were used in collecting primary data. Secondary data was however sourced from National Bank of Rwanda reports and annual internal reports of Equity Bank Rwanda Plc. Questionnaires were distributed to respondents after getting approval from the Equity Bank Rwanda Plc. Management. data was collected for a period of one week. 
Data analysis

Data analysis involved use of descriptive statistics approach. Additionally, inferential statistics was also utilized in achieving study objectives. This involved conducting correlation and regression analysis. IBM SPSS version 21 was utilized to process, analyze the data and compute findings. Content analysis was adopted in the analysis of qualitative data. Data was analyzed using means and percentages and presented in form of tables and graphics. The regression model used to link the financial fraud and bank performance was as follows.

$Y=\beta_{0}+\beta_{1} X_{1}+\beta_{2} X_{2}+\beta_{3} X_{3}+\propto$ Where $\mathrm{Y}, \mathrm{X}_{1}, \mathrm{X}_{2}$ and $\mathrm{X}_{3}$ and $\propto$ are bank performance, fraudulent loans, fraudulent invoices, identity theft and error term respectively. $\beta_{S}$ represent regression coefficients.

\section{RESEARCH FINDINGS AND DISCUSSION}

\section{Presentation of Findings}

This study aimed at investigating the effects of financial frauds on commercial banks performance taking a case of Equity Bank Rwanda Plc. The forms of financial fraud that the study focused on included fraudulent loans, fraudulent invoices and identity theft. This section presents the findings on these forms of financial fraud and their effects on bank performance.

\section{Fraudulent Loans and commercial banks performance}

Respondents opinion on statements regarding fraudulent loans and bank performance are summarized in below table. The scale range was from 1 to 5 where 1, 2, 3, 4, 5 represented not frequent, rarely frequent, less frequent, frequent and highly frequent respectively. The results are summarized in the following table.

Table 1: Frequency of Occurrence of Fraudulent Loans at Equity Bank Rwanda Plc

\begin{tabular}{lccccc}
\hline Statement & frequent & $\begin{array}{c}\text { Less } \\
\text { frequent }\end{array}$ & $\begin{array}{c}\text { Rarely } \\
\text { frequent }\end{array}$ & $\begin{array}{c}\text { Not } \\
\text { frequent }\end{array}$ & $\begin{array}{c}\text { mean } \\
\text { Std } \\
\text { Dev }\end{array}$ \\
\hline $\begin{array}{l}\text { Multiple businesses registered } \\
\text { by one loan applicant }\end{array}$ & $33 \%$ & $34 \%$ & $33 \%$ & 2.00 & 0.817 \\
$\begin{array}{l}\text { Non physical presence of clients } \\
\text { business }\end{array}$ & $31 \%$ & $26 \%$ & $43 \%$ & 1.88 & 0.856 \\
Unclear business plans & & & & & \\
Inflated business earnings & $35 \%$ & $30 \%$ & $35 \%$ & 2.00 & 0.841 \\
Unaudited financial statements & $32 \%$ & $39 \%$ & $29 \%$ & 2.03 & 0.784 \\
Few or non-reputable referees & $21 \%$ & $33 \%$ & $46 \%$ & 1.75 & 0.783 \\
\hline
\end{tabular}

\section{Source: Primary data, 2021}

From the above results, $33 \%$ of respondents indicated that cases of multiple business registered by one loan applicant occur less and not frequently whereas $34 \%$ indicated that such cases rarely occur. Regarding non-physical presence of clients' business, $31 \%$ and $26 \%$ agreed that they occur less frequently and rarely frequent respectively at Equity Bank Rwanda Plc. while $43 \%$ were of the opinion that they occur not frequently. Additionally, unclear business plans presented by clients occur less frequently supported by 35\% of respondents, occur rarely frequent at 30\% and 35\% of respondents indicated that it does not frequently occur. Moreover, the results did indicate that $32 \%, 39 \%$ and $29 \%$ of respondents agreed that customers presenting inflated business in order to increase their chances of getting a loan is less frequent, rarely frequent and not frequent respectively. Further, $21 \%$ of respondents opined that unaudited financial statements occur less frequently at Equity Bank Rwanda Plc. while 33\% were of the opinion that it occurs rarely and finally $46 \%$ of respondents did indicate that it doesn't occur frequently. Last but not least, based on the cases of few or non-reputable referees, the findings did indicate that the $35 \%$ of respondents agreed that it occurs less frequently while $34 \%$ and $31 \%$ were for the rare occurrence and not frequent occurrence respectively. Lastly, the mean values for all cases of fraudulent loans presented was reported at approximately 2 which implies that the fraudulent loans rarely occur at Equity Bank Rwanda Plc. 


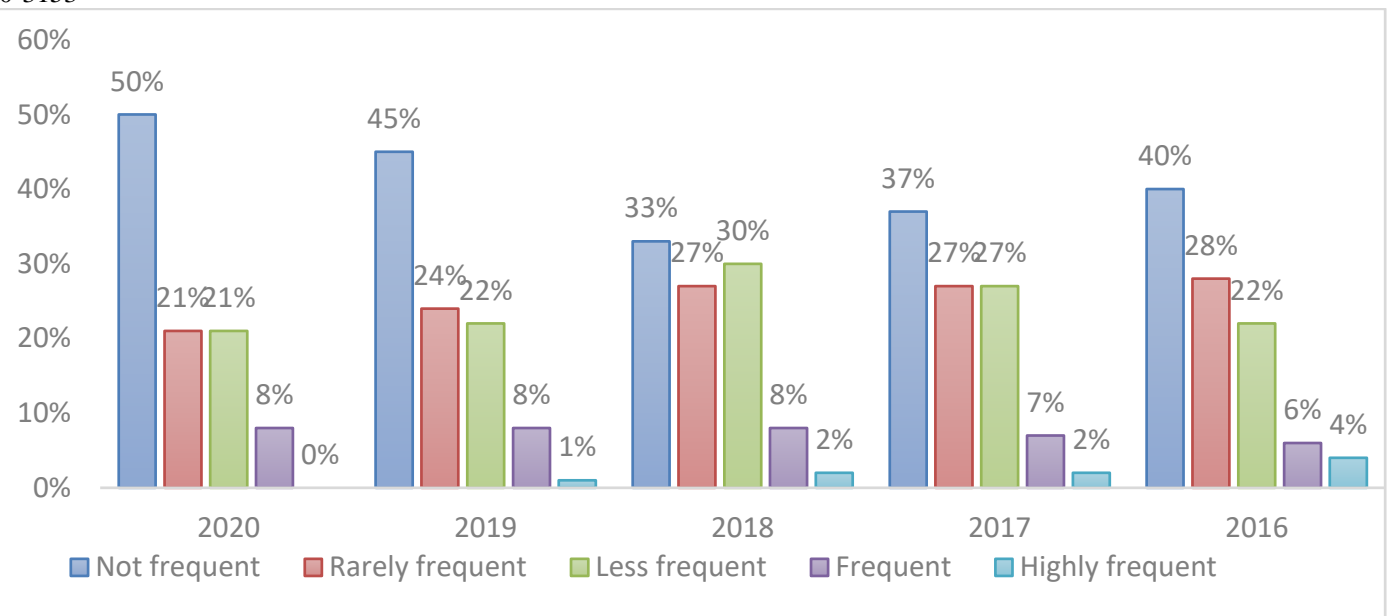

Figure 2: Frequency of Occurrence of Fraudulent Loans for past 5 years at Equity Bank Rwanda Plc

The above figure indicates that $50 \%, 45 \%, 33 \%, 37 \%$ and $40 \%$ of respondents opined that fraudulent loans were not frequent for the years 2020, 2019,2018,2017 and 2016 respectively. Regarding whether fraudulent loans were rarely frequent, 21\%, 24\%, 27\%, 27\% and $28 \%$ of respondents supported for 2020 down to 2016 respectively. The respondents who stated that occurrence of fraudulent loans at Equity Bank Rwanda Plc. was less frequent were 21\%, 22\%, 30\%, 27\% and 22\% respectively for the five years staring 2020 downwards. Additionally, $8 \%$ of respondents were of the opinion that fraudulent loans cases occurred frequently in 2020, 2019 and 2018. However, 7\% and 6\% of respondents were of the same opinion for 2017 and 2016 respectively. Lastly $1 \%$ of respondents indicated that fraudulent loans cases were highly frequent in 2019 while $2 \%$ were of the same opinion in 2018 and 2017 and finally $4 \%$ indicated the same in 2016.

Table 2: Correlation between fraudulent loans and Bank Performance

\section{Fraudulent loans}

Bank performance

Fraudulent loans

Pearsons Correlation

1

$-.690^{* * *}$

Sig. (2-tailed)

.031

$\mathrm{N}$

100

100

Bank performance Pearsons Correlation

$-.690^{* *}$

1

Sig. (2-tailed)

.031

$\mathrm{N}$

100

100

Source: Primary data 2021

The results above show that the Pearson correlation coefficient is -0.690 with a significance value of 0.031 (Table 2). This indicates a moderate negative significant association between fraudulent loans and bank performance. Therefore, when fraudulent loan cases reduce, profitability of the bank increases.

\section{Fraudulent Invoices and Commercial Banks Performance}

Invoices are requests for payments to be executed. Due to advancement in technology banks may receive forged invoices and make payments based on such. The researcher gathered respondents' opinions on the various ways in which fraudulent invoices may occur to ascertain the frequency of occurrence at Equity Bank Rwanda Plc. 
Table 3: Frequency of Occurrence of Fraudulent Invoices at Equity Bank Rwanda Plc

\begin{tabular}{lccccc}
\hline Statement & frequent & $\begin{array}{c}\text { Less } \\
\text { frequent }\end{array}$ & $\begin{array}{c}\text { Rarely } \\
\text { frequent }\end{array}$ & $\begin{array}{c}\text { Not } \\
\text { frequent }\end{array}$ & $\begin{array}{c}\text { mean } \\
\text { Std } \\
\text { Dev }\end{array}$ \\
\hline Receipt of fake invoices & $31 \%$ & $35 \%$ & $34 \%$ & 1.97 & 0.810 \\
Payment of fraudulent cheques & $28 \%$ & $31 \%$ & $41 \%$ & 1.87 & 0.824 \\
Fraudulent change of customer & $38 \%$ & $31 \%$ & $31 \%$ & 2.07 & 0.831 \\
account details & & & & & \\
Fraudulent supplier payments & $23 \%$ & $33 \%$ & $44 \%$ & 1.79 & 0.795 \\
Payment of inflated invoices & $23 \%$ & $35 \%$ & $42 \%$ & 1.81 & 0.787 \\
\hline
\end{tabular}

Source: Primary data, 2021

From the table above, $31 \%$ of respondents stated that receipt of fake invoices is less frequent at Equity Bank Rwanda Plc, $35 \%$ stated that it's rare to find the bank receipting fake invoices whereas $34 \%$ stated that the receipt of fake invoices is not frequent at Equity Bank Rwanda Plc. The results also show that $28 \%, 31 \%$ and $41 \%$ of respondents did indicate that at Equity Bank Rwanda Plc. payment of fraudulent cheques occur less frequently, rarely occur and not frequently occur respectively. The results further indicate that $38 \%, 31 \%$ and $31 \%$ of respondents opined that at Equity Bank Rwanda Plc. fraudulent change of customer account details is less frequent, rarely frequent and not frequent respectively. Additionally, $23 \%$ of respondents did indicate that fraudulent supplier payments are less frequent at Equity Bank Rwanda Plc. while 33\% and 44\% were for rarely frequent and not frequent in that order. Lastly, 23\% of respondents stated that cases of payment of inflated invoices are less frequent at Equity Bank Rwanda Plc. However, 35\% of respondents were of the opinion that payment of inflated invoices does occur rarely while $42 \%$ reported that such cases are not frequent. These results widely show that cases of fraudulent invoices are very minimal at Equity Bank Rwanda Plc.

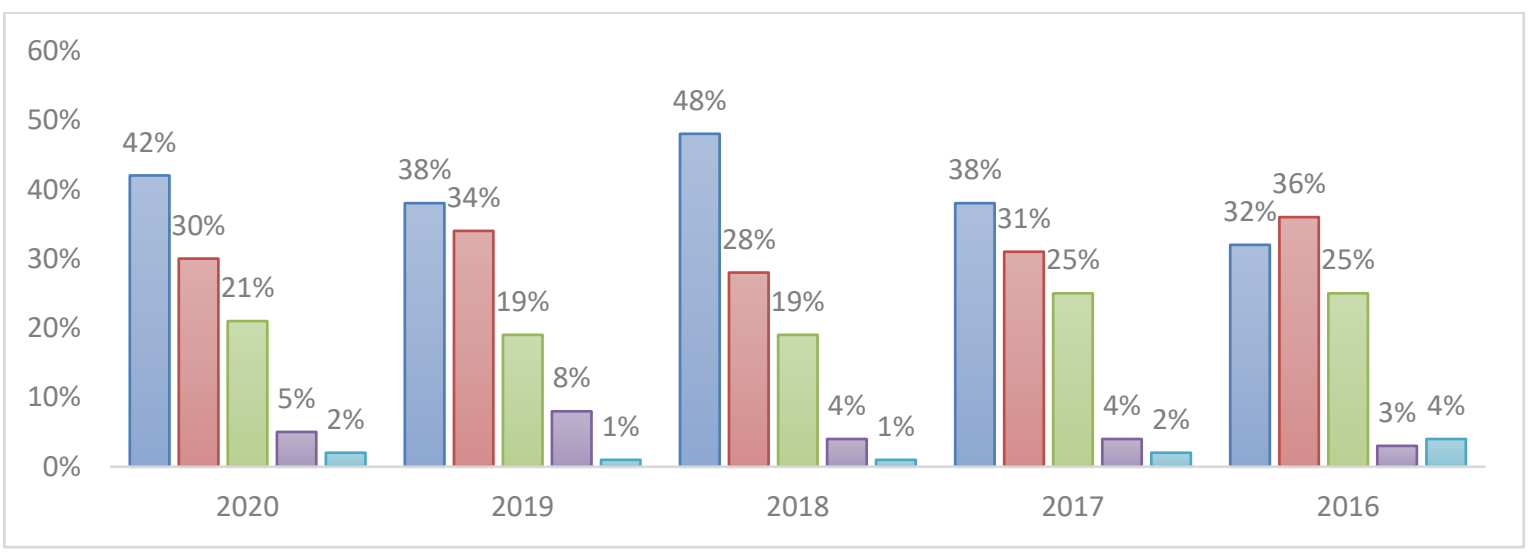

Figure 3: Fraudulent Invoices Occurrence at Equity Bank Rwanda Plc for the past 5 Years

The above figure 3 indicate that $42 \%, 38 \%, 48 \%, 38 \%$ and $32 \%$ of respondents opined that fraudulent invoices were not frequent for the years 2020, 2019,2018,2017 and 2016 respectively. Regarding whether fraudulent invoices were rarely frequent, 30\%, 34\%, 28\%, 31\% and $36 \%$ of respondents supported for 2020 down to 2016 respectively. The respondents who stated that occurrence of fraudulent invoices at Equity Bank Rwanda Plc. was less frequent were 21\%, 19\%, 19\%, 25\% and 25\% respectively for the five years staring 2020 downwards. Additionally, some respondents were of the opinion that there were frequent fraudulent invoice cases from 2020 down to 2016 accounting for $5 \%, 8 \%, 4 \%, 4 \%$ and $3 \%$ respectively. Lastly the findings did indicate that $2 \%$ of respondents were of the view that fraudulent invoices were highly frequent in 2020 and 2017 while $1 \%$ indicated that they were highly frequent in 2019 and 2018 and finally $4 \%$ did indicate high frequency of occurrence of fraudulent invoices in 2016. 
Table 4: Correlation between Fraudulent Invoices and Bank Performance

\begin{tabular}{cccc}
\hline & & Fraudulent invoices & Bank performance \\
\hline Fraudulent invoices & Pearsons Correlation & 1 & $-.630^{* *}$ \\
& Sig. (2-tailed) & & .028 \\
Bank performance & $\mathrm{N}$ & 100 & 100 \\
& Pearsons Correlation & $-.630^{* *}$ & 1 \\
& Sig. (2-tailed) & .028 & 100 \\
\hline
\end{tabular}

\section{Source: Primary data 2021}

The findings indicate a Pearson correlation coefficient of -0.630 and significance value of 0.028 . Since the Pearson coefficient value is above 0.5 but less than 0.7 in absolute terms, there is a moderate association between fraudulent invoices and bank performance. the relationship between the two is negative indicated by the negative sign of the correlation coefficient. Lastly the relationship between fraudulent invoices and bank performance is significant since the significance value of 0.028 is less than 0.05 .

\section{Identity theft and Commercial Banks Performance}

The last form of financial fraud that the study focused on is identity theft where the person's identity details are accessed by someone else hence able to access the financial details of the person. This can cause theft of funds since the person can easily access the accounts of the victim. There is possibility that such cases can taint the name of the bank negatively and reduce its financial performance hence need for appropriate measures to curb the vice.

Table 5: Frequency of Occurrence of Identity Theft at Equity Bank Rwanda Plc

\begin{tabular}{lcccccc}
\hline Statement & frequent & $\begin{array}{c}\text { Less } \\
\text { frequent }\end{array}$ & $\begin{array}{c}\text { Rarely } \\
\text { frequent }\end{array}$ & $\begin{array}{c}\text { Not } \\
\text { frequent }\end{array}$ & mean & $\begin{array}{c}\text { Std } \\
\text { Dev }\end{array}$ \\
\hline Credit card theft & 27 & 38 & 35 & 1.92 & 0.787 \\
Debt card theft & 32 & 37 & 31 & 2.01 & 0.798 \\
Theft of customer passport/national & 27 & 40 & 33 & 1.94 & 0.776 \\
$\begin{array}{l}\text { ID numbers } \\
\text { Theft of account numbers and PIN }\end{array}$ & 29 & 40 & 31 & 1.98 & 0.778 \\
$\begin{array}{l}\text { Fraudulent change of personal } \\
\text { address }\end{array}$ & 17 & 35 & 46 & 1.75 & 0.809 \\
\hline
\end{tabular}

\section{Source: Primary data, 2021}

The findings in the above table 5 indicate that $27 \%, 38 \%$ and $35 \%$ of respondents did indicate that theft of credit card is less frequent, rarely frequent and not frequent respectively. In terms of debt card theft, the $32 \%$ and $37 \%$ of respondents opined that they less and rarely frequent while $31 \%$ indicated that they are not frequent. Theft of customer passport or national ID numbers was perceived to be less frequent by $27 \%$ of respondents and rarely frequent by $40 \%$ of respondents though $33 \%$ indicated that it's not a frequent occurrence at Equity Bank Rwanda Plc. Additionally, theft of account numbers and PIN was supported by $29 \%$ of respondents as being less frequent and $40 \%$ as being rarely frequent at Equity Bank Rwanda Plc. while $31 \%$ opined that such cases are not frequent. Last but not least, the findings indicated that $17 \%$ of respondents were of the view that fraudulent change of personal address is less frequent while $35 \%$ indicated that this practice is rarely frequent and a majority of respondents at $46 \%$ reported that the practice is not frequent at Equity Bank Rwanda Plc. lastly the mean values from the table indeed are all ranging at approximately 2 which indicates that all the forms of identity theft highlighted are rarely frequent at Equity Bank Rwanda Plc. These results generally show that the identity theft practices are not common at Equity Bank Rwanda Plc though they occur. 


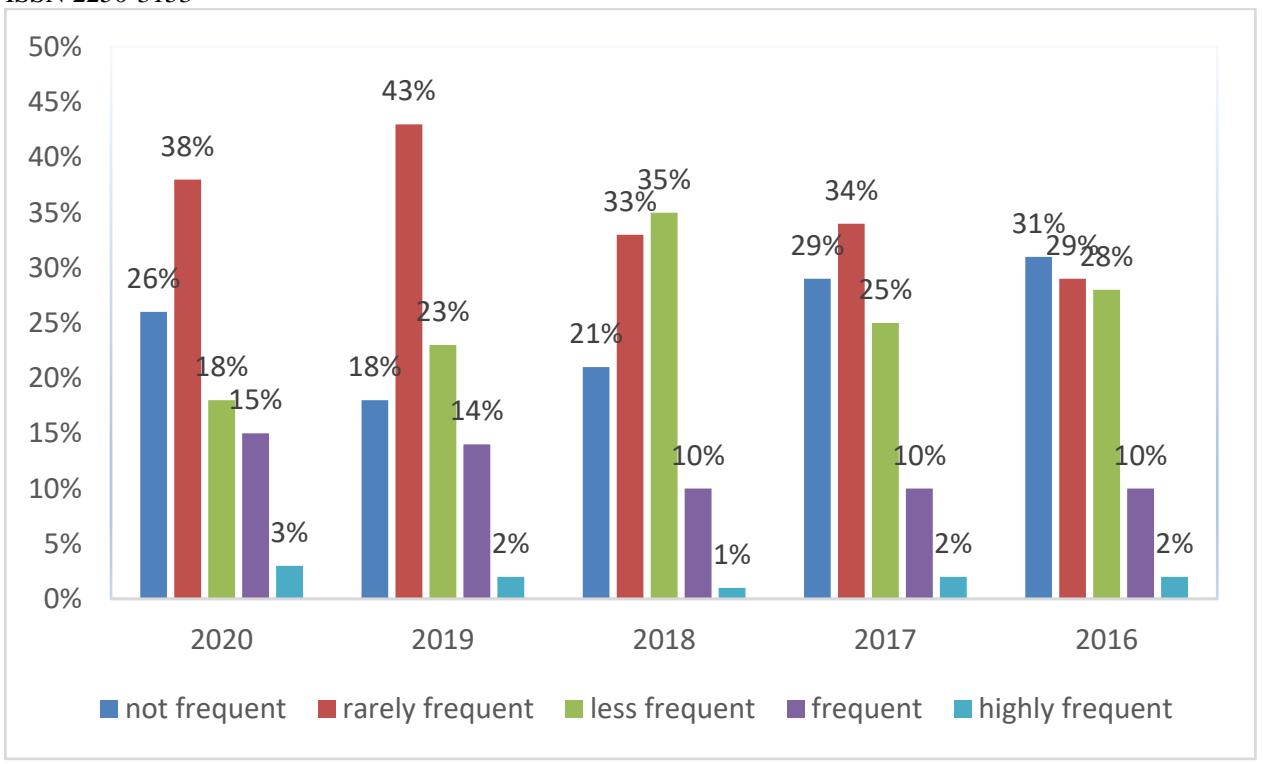

Figure 4: Identity Theft Occurrence at Equity Bank Rwanda Plc for past 5 Years

From the above figure 4, 38\%, 43\%, 33\%, 34\% and $29 \%$ of respondents opined that the occurrence of identity theft was very rare between 2016 and 2020 respectively in a descending order. Additionally, 26\%,18\%, 21\%, 29\% and 31\% of respondents stated that identity theft cases were not frequent for 2020, 2019, 2018, 2017 and 2016 respectively. Moreover, $18 \%, 23 \%, 35 \%, 25 \%$ and $28 \%$ of respondents did state that the occurrence of identity theft at Equity Bank Rwanda Plc. was less frequent for 2020 to 2016 respectively in a descending order. Last but not least, $15 \%, 14 \%, 10 \%, 10 \%$ and $10 \%$ of respondents did indicate that identity theft occurrence was frequent in 2020 going down to 2016 respectively. Lastly, 3\%, 2\%, 1\%, 2\% and $2 \%$ of respondents were of the opinion that the occurrence of identity theft was highly frequent from 2020 down to 2016 respectively. These results indeed indicate that generally the occurrence of fraudulent loans at Equity Bank Rwanda Plc. has been very rare for the past 5 years indicating the effectiveness of the measures put in place to minimize the occurrence of identity theft frauds.

Table 6: Correlation between Identity Theft and Bank Performance

Identity theft Bank performance

Identity theft

\begin{tabular}{|c|c|c|c|}
\hline \multirow{5}{*}{ Bank performance } & Sig. (2-tailed) & & .014 \\
\hline & $\mathrm{N}$ & 100 & 100 \\
\hline & Pearson's Correlation & $-.650^{* *}$ & 1 \\
\hline & Sig. (2-tailed) & .014 & \\
\hline & $\mathrm{N}$ & 100 & 100 \\
\hline
\end{tabular}

\section{Source: Primary data 2021}

The findings above indicate a Pearson's correlation coefficient of -0.650 and a significant value of 0.014 . The Pearson's correlation coefficient is negative and falls between 0.5 and 0.7 an indication that there is a moderate negative association between identity theft and bank performance. when there is a reduction in identity theft cases the bank performance increases in terms of profitability. Additionally, the association between identity theft and bank performance is significant indicated by the significant value which is less than 0.05 . 


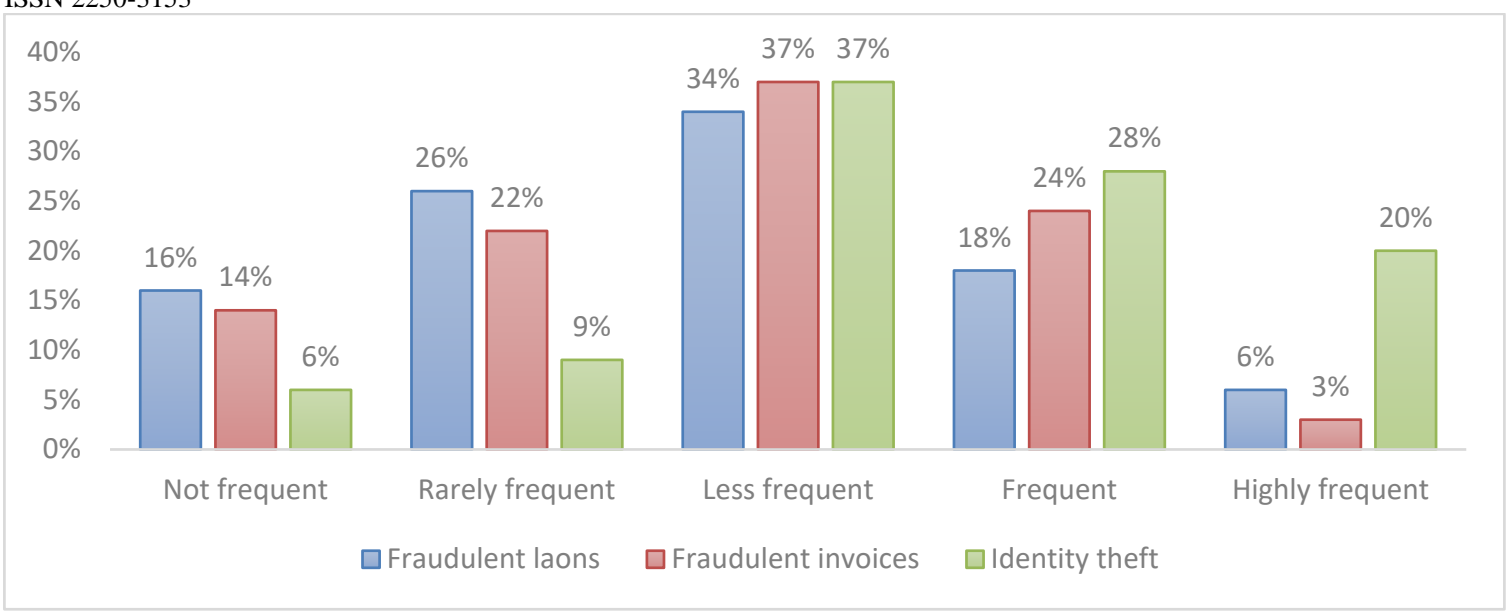

Figure 5: Frequency of Frauds Occurrence in the Banking Sector

The results indicate that $16 \%, 26 \%, 34 \%, 18 \%$ and $6 \%$ of respondents are of the opinion that fraudulent loans occur not frequently, rarely frequent, less frequent, frequent and highly frequent respectively. additionally, $14 \%, 22 \%, 37 \%, 24 \%$ and $3 \%$ of respondents indicated that fraudulent invoices occur in the banking sector not frequently, rarely frequent, less frequent, frequent and highly frequent respectively. lastly the results indicate that $6 \%, 9 \%, 37 \%, 28 \%$ and $20 \%$ opined that the occurrence of identity theft in the banking sector is not frequent, rarely frequent, less frequent, frequent and highly frequent respectively. these results indeed confirm that as much as banks are trying to minimize the cases of financial fraud, they are still there as evidenced by a good percentage of respondents who indicated that the cases are still frequent and some even indicating that they highly frequent. The results actually show that financial frauds result mostly from identity theft, followed by fraudulent invoices and lastly fraudulent loans. However, these cases are widely minimal as majority indicated that financial fraud cases are not, rarely or less frequent with majority indicating that financial frauds do occur less frequently.

\section{Fraud control mechanisms and bank financial performance}

The researcher looked at the contributions of the internal and external mechanisms in place towards reducing financial fraud in the banking sector.

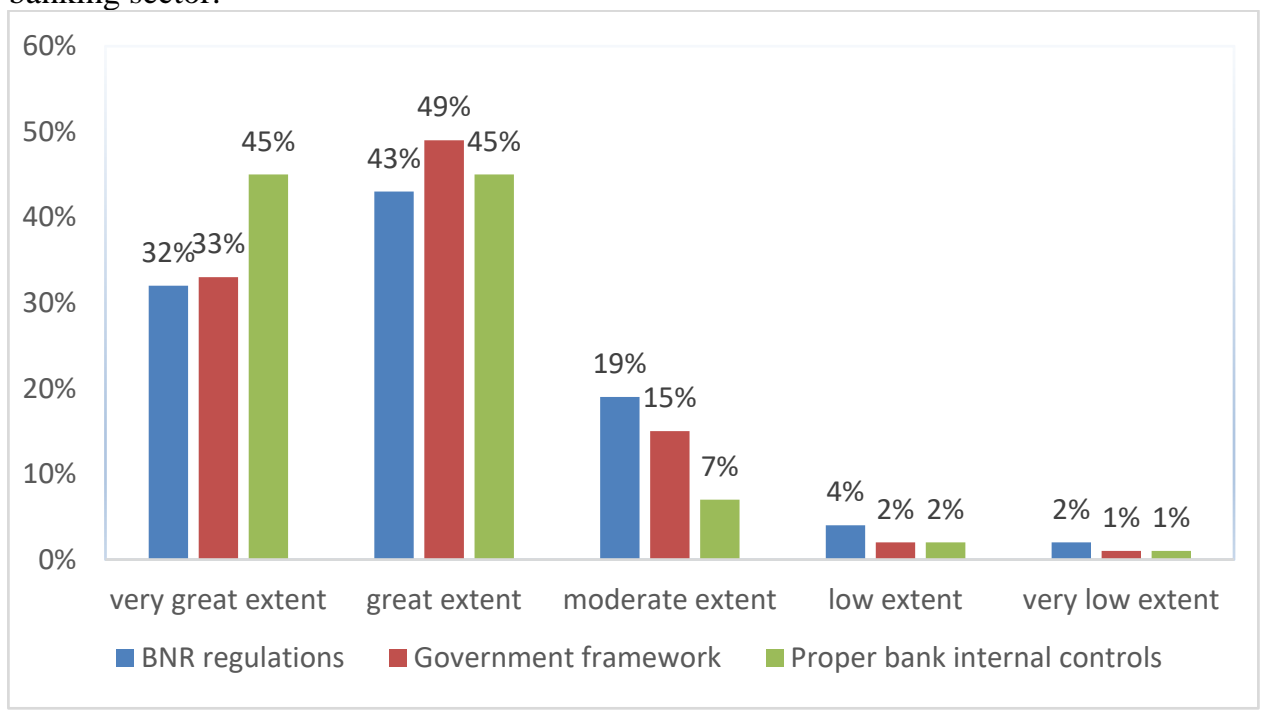

\section{Figure 6: Fraud Control Mechanisms and Bank Performance}

The results above show that BNR regulations contribute a lot towards controlling financial frauds. This was evidenced by a greater percentage accounting for $94 \%$ indicating that such regulations contribute to a moderate, great and very great extent towards controlling financial frauds. However, $6 \%$ opined that BNR regulations contribute to financial frauds control to low and very low extent. Regarding government framework, $97 \%$ of respondents did agree that they contribute to a moderate, great and very great extent towards controlling 
financial frauds in the banking sector. However only an insignificant number of 3\% indicated the contrary opinion. Lastly proper bank internal control mechanisms in place was also found to contribute greatly in controlling financial frauds supported by $90 \%$ of respondents and moderate contribution supported by $7 \%$ of respondents. On the contrary only an insignificant number of 3\% of respondents stated that proper bank internal controls contribute to a low and very low extent towards controlling financial frauds.

\section{Regression Analysis}

In order to ascertain the effects of financial frauds particularly fraudulent loans, fraudulent invoices and identity theft on bank performance, regression analysis was conducted and the results were as follows.

Table 7: Model Summary

\begin{tabular}{llll}
\hline Model R Square & Adjusted R Square & Std. Error of the Estimate
\end{tabular}

$\begin{array}{llll}1 & .624 & .612 & .45382\end{array}$

\section{Source: Primary data, 2021}

The model summary above indicate that $\mathrm{R}$ squared value is 0.624 equivalent to $62.4 \%$. this implies that the three forms of financial fraud discussed in this study including fraudulent loans, fraudulent invoices and identity theft explains $62.4 \%$ of the variations in bank financial performance. the remaining $37.6 \%$ of the variations in bank financial performance are explained by other determinants of bank performance other than the three forms of financial fraud in this study.

Table 8: ANOVA

\begin{tabular}{lcccc}
\hline Model & Sum of Squares & Df & F Statistic & Significance \\
\hline Regression & 32.789 & 3 & 53.069 & 0.000 \\
Residual & 19.771 & 96 & & \\
Total & 52.560 & 99 & & \\
\hline
\end{tabular}

Dependent variable: Bank Performance

\section{Source: Primary data 2021}

Analysis of variance is conducted to ascertain the validity of the model used to analyze the relationship between or among variables. The study conducted a Two-Way ANOVA and the results from the table above indicate that F statistic value is 53.069 and the significance value is 0.000 . The $\mathrm{F}$ table value for $\mathrm{F}(3,96)$ at alpha value of 0.01 is 3.95 which is less than $\mathrm{F}$ calculated value of 53.069. This implies that the null hypothesis of the inappropriateness of the linear regression model used in this study is rejected. Therefore, the linear regression model used to show the relationship between financial fraud and bank performance adopted in this study is appropriate.

Table 9: Model Coefficients

\begin{tabular}{lcccc}
\hline Model & Coefficient & Std Error & T Statistic & Significance \\
\hline Constant & 6.072 & .174 & 34.902 & .000 \\
Fraudulent loan & -.151 & .072 & -2.094 & .039 \\
Fraudulent invoice & -.581 & .076 & -7.627 & .000 \\
Identity theft & -.431 & .080 & -5.413 & .000 \\
\hline
\end{tabular}

Dependent Variable: bank performance

This publication is licensed under Creative Commons Attribution CC BY. 
The above table 9 shows the coefficients of the regression model and the significance values. From the table the coefficient term is 6.072 while the coefficients for fraudulent loan, fraudulent invoice and identity theft is - $.151,-.581$ and -.431 respectively. This implies that as financial fraud cases increases, bank performance reduces. The significant value for constant term, fraudulent invoice and identity theft is 0.000 while that of fraudulent loan is 0.039 . The dependent variable is bank performance. When there are no effects of financial fraud variables, bank performance value stands at 6.072. Keeping other factors constant, $1 \%$ change in fraudulent loans, fraudulent invoices and identity theft leads to a $15.1 \%, 58.1 \%$ and $43.1 \%$ change in bank performance in the opposite direction. A reduction in financial fraud leads to an increase in bank performance as indicated by negative signs of the predictor variables. The effects of financial fraud on bank performance is strongly significant since the p values for all the predictor variables are less than 0.05 and all are zero except in the case of fraudulent loans.

$Y=6.072-0.151 X_{1}-0.581 X_{2}-0.431 X_{3}+\propto$ Where $\mathrm{Y}, \mathrm{X}_{1}, \mathrm{X}_{2}$ and $\mathrm{X}_{3}$ and $\propto$ are bank performance, fraudulent loans, fraudulent invoices, identity theft and error term respectively.

\section{Discussion}

\section{Effect of fraudulent loan on commercial bank performance}

Determining the effects of fraudulent loans on commercial bank performance formed the first objective of this study. The researcher gathered data from the respondents and analyzed in order to achieve this objective. Descriptive analysis involved seeking respondents' opinion on the state of fraudulent loans occurrence in the banking sector in general and also specifically at Equity Bank Rwanda Plc. The various forms of fraudulent loans or potential causes of fraudulent loans was assessed from respondents including non-physical presence of customers' business, unclear business plans, non-reputable referees, multiple businesses registered by loan applicant, inflated business earnings and unaudited. All these factors may lead to fraudulent loans being processed. The findings did indicate that these practices are less, rarely or not frequent at Equity Bank Rwanda Plc. meaning that there are prudent policies put in place to avoid occurrence of fraudulent loans at Equity Bank Rwanda Plc. Additionally, fraudulent loans were found to a large extent not frequent in the banking sector though they occur.

Correlation findings did indicate Pearson correlation coefficient of -.690 and significance value of 0.031 which implies that there is moderate negative significant association between fraudulent loans and commercial bank performance. Moreover, regression analysis indicates that $1 \%$ fall in fraudulent loans leads significant increase in bank performance by $15.1 \%$ keeping other factors constant. Therefore, these results show that fraudulent loans have negative significant effect on bank performance. for the bank to improve its performance appropriate measures must be in place to minimize or eliminate the occurrence of fraudulent loans.

These results are in concurrence with those of Odhiambo (2013) who conducted a study in Kenya on financial fraud and liquidity on financial performance of commercial banks. The study in deed established that financial fraud on form of fraudulent loans reduces bank liquidity and therefore negatively affects financial performance of commercial banks. Additionally, this study concurs with NDIC (2010) research which found that financial frauds may plunge the bank in a liquidity trap where by its not able to have enough funds to give as loans and being that loans interests are major source of revenue for banks, frequent occurrence of financial frauds may negatively affect bank profitability.

\section{Effect of fraudulent invoices on commercial bank performance}

The second objective of the study focused on examining the effects of fraudulent invoices on commercial banks performance. the study analyzed descriptively the status of fraudulent invoice occurrence in the banking sector. The major avenues of fraudulent invoices that the study explored included receipt of fake invoices, payment of fraudulent cheques, payment of inflated invoices, fraudulent supplier payments and fraudulent change of customer account details. The study however established that the occurrence of these avenues of fraudulent invoice payments are widely less and rarely frequent at Equity Bank Rwanda Plc. However, the study established that the cases of fraudulent invoice payments indeed exists but not frequent. Fraudulent invoices though not frequently occur in the banking sector, it's evident in the banking sector as supported by a significant percentage of respondents. This practice puts the bank in a liquidity problem since it may be forced to refund to the customer fraudulent payments committed if actually the customer did not approve such payments.

Correlation findings did indicate that there is moderate significant negative relationship between fraudulent invoices and bank financial performance. This implies that an increase in cases of fraudulent invoices being processed leads to a fall in bank profitability hence financial performance goes down. Additionally, there is $58.1 \%$ chances of increased bank performance if there is $1 \%$ reduction in fraudulent invoices cases. This shows the greatest negative effect that fraudulent loans have on bank performance. This supports the study findings of (Gates and Jacob,2009) who opined that bank frauds not only affect the bank but also the customers. Banks are forced to refund to their customers' money lost through banks mistake and the customers on the other hand bear the burden of inconvenience in terms of opening a new account and changing account details which are both time and financially consuming. Additionally, the study 
also concurs with the findings of Akindele (2011) findings in Nigeria who argued that bank frauds are a negative catalyst in the banking sector as they reduce bank profitability and financial performance. However, the study findings are against those of Kiragu et al (2013) in Kenya who established that bank frauds do not have any effect on the growth of commercial banks.

\section{Effect of Identity theft on commercial bank performance}

Identity theft is a situation where personal identity details are stolen by someone else who then benefits by accessing the accounts hence causing financial damage to the victim. The study assessed the status of identity theft at Equity Bank Rwanda Plc. and in the general banking sector. The study established that at Equity Bank Rwanda Plc. Identity theft cases are minimal though they occur. these include theft of debt card, credit card, theft of personal address, ID numbers, account numbers and PIN numbers among others. In the general banking sector, the study established that there is a moderate occurrence of identity theft in the banking sector. Technology advancement has brought insecurity challenges since fraudsters can manipulate the systems and get access to some information regarding someone and this poses a threat to the victim. Additionally, these fraudsters can collude with workers in the banking sector and get some information regarding the identity of a person hence exposing the person to financial risks.

The study conducted correlation between identity theft and bank performance and established moderate negative association between the two. This implies that as identity theft cases increases, bank performance reduces and vice versa. Additionally, regression analysis findings did indicate that there is significant negative effect of identity theft on bank financial performance. A $1 \%$ reduction in identity theft cases results to $43.1 \%$ chances of increased bank performance keeping other factors constant. These findings support various findings from other countries who also found negative significant effects of identity theft on bank financial performance (Gates and Jacobs, 2009, Akindele, 2011, Odhiambo,2013).

\section{SUMMARY, CONCLUSSION AND RECOMMENDATIONS}

\section{Summary}

The summary of the findings of this researchwere based on the objectives that the study sought to achieve.

\section{To assess the effects of fraudulent loans on performance of commercial banks}

In order to achieve this objective, the study sought opinion of respondents on the frequency of occurrence of cases of fraudulent loans at Equity Bank Rwanda Plc. and banking sector as a whole. Additionally, the study conducted correlation and regression analysis to ascertain the relationship between the variables and the effects of fraudulent loans on bank performance. the study established that cases of fraudulent loans though occur are rare and less frequent at Equity Bank Rwanda Plc. however they are significantly frequent in the banking sector. The findings also indicate that for the past 5 years, the occurrence of fraudulent loans has been less, rarely or not frequent at Equity Bank Rwanda Plc. Correlation findings did indicate that Pearson correlation coefficient was -0.690 with a significance of 0.031 while the regression findings indicated that the beta coefficient for fraudulent loans was -.151 with a significance value of .039 . This implies that the effects of fraudulent loans on bank performance are negative and significant. The association between fraudulent loans and bank performance is inverse and moderate.

\section{To determine the effects of fraudulent invoices on performance of commercial banks}

The results of this study regarding the effects of fraudulent invoices on performance of commercial banks were presented in both descriptive and inferential forms. Descriptive findings involve examining the frequency of occurrence of fraudulent invoices at Equity Bank Rwanda Plc. and banking sector as a whole. The findings did indicate that at Equity Bank Rwanda Plc., the cases of fraudulent loans are there but less, rare and not frequently occurring. However, in the entire banking sector these cases are significantly frequent supported by significant percentage of respondents (27\%). Correlation analysis did indicate a Pearson correlation coefficient of -0.630 and significance value of 0.028. regression findings on the had indicated beta coefficient of -.581 with a significance value of 0.000 . this is an implication that the relationship between fraudulent invoices is negative and significant and that the effects of fraudulent invoices on bank performance are negative.

\section{To determine the effects of identity theft on performance of commercial banks}

The last objective of this study was to determine the effects of identity theft on bank performance. Descriptive findings revealed that identity theft is less, rarely and not frequent occurring at Equity Bank Rwanda Plc. However, the findings revealed that identity theft frequently occurs in the banking sector supported by nearly half of the study respondents (48\%). Theft of ID numbers, debt and credit cards, account numbers and personal address are found to be frequent in the banking sector according to this study finding. The study further revealed that for the past 5 years, identity theft cases have been there but largely less and rarely frequent at Equity Bank Rwanda Plc though they are on the rise in the banking sector as indicated earlier. Correlation findings indicated a Pearson correlation coefficient between identity theft and bank performance of -0.650 with a significance of 0.014 . additionally, regression analysis findings indicated 
that beta coefficient for identity theft is -.431 with significance value of 0.000 . This implies that identity theft and bank performance are negatively and significantly related and that identity theft has negative effects on bank performance.

\section{Conclusion}

Based on the above findings, the study came up with some conclusions in line with objectives.

First, regarding the effects of fraudulent loans on bank performance, the study concludes that there is a negative significant effects of fraudulent loans on commercial banks financial performance. This was exhibited by the fact that the correlation findings revealed a negative correlation coefficient with a significance value of less than $5 \%$. Additionally, the coefficient of fraudulent loans in the regression analysis was negative with $\mathrm{p}$ value less than 0.05 . An increase in fraudulent loans negatively affects commercial banks financial performance.

Secondly, the study concludes that fraudulent invoices have negative significant effects on commercial banks financial performance. A reduction in fraudulent invoices cases results into an increase in bank financial performance. fraudulent invoices make banks to facilitate payments which are based on invalid documents or information which can ultimately lead to the bank losing its liquidity since it results to refunding the customer if the bank is on the wrong side. Therefore, the bank loses money which could be part of its liquidity base.

Thirdly, the study concludes that identity theft has a significant negative effect on bank financial performance. An increase in identity theft cases leads to a reduced bank performance. the beta coefficient for identity theft is negative and Pearson correlation coefficient is also negative meaning that identity theft and bank financial performance are inversely related. Once a person's identity documents are stolen, the person's financial records can be accessed and the fraudsters can easily conduct transactions using the accounts of the victim. Additionally, it's also possible that someone can easily take loans and enjoy other financial advantages once he or she is in possession of identity documents. For example, debt card and PIN theft can make someone to withdraw money from one's account easily without detection.

Lastly the study concludes that financial fraud cases though not frequent, there occurrence commands a significant percentage in the banking sector more so identity theft. The great role that the various control mechanisms in place also contributes to financial performance. Particularly the BNR, Government framework and bank proper internal control mechanisms in place contributes to a greater extent towards reducing financial frauds hence improved financial performance. 


\section{Recommendation}

The study recommends that commercial banks should put in place fraud detection mechanisms and strengthen risk department to ensure that potential fraud risks are detected on time to avoid their occurrence. Additionally, banks should continue creating awareness to their customers on the appropriate ways of managing their accounts for example being sensitive with their identity details and immediately report to the bank in case they have lost or shared unwillingly identity documents. This will ensure speedy action is taken before damage.

Additionally, the study recommends appropriate scrutiny of loan applicants documents to ensure they are true documents. Banks should also invest in proper monitoring of loans taken to ensure that true figures and documents are kept to avoid risk of default or fraud. This is achieved by ensuring that credit and risk department is well resourced with appropriate technology and human skills able to detect fraudulent loan application documents and act swiftly to minimize risk occurrence hence boost financial performance.

Lastly the study recommends strict adherence to the control mechanisms in place within and outside the bank. Internal control mechanisms should be adhered to and periodic transparent audits should be enhanced in all the departments to ensure that quality guidelines are adhered to which is beneficial to the banks performance. Additionally, trainings should be continuously conducted on leadership and corporate governance to ensure that unethical issues are addressed and enhance proper management of the bank which ultimately leads to improved bank performance.

\section{Suggestions for Further study}

This study focused on financial fraud and performance of commercial banks. More studies can be conducted on financial fraud and the performance of other financial institutions such microfinance institutions and insurance firms which also deal with advancing loans and protection against risk respectively hence frauds can be eminent.

\section{REFERENCES}

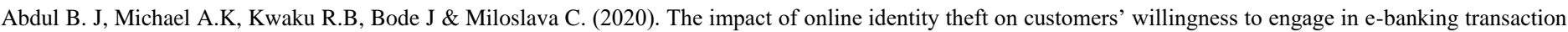
in Ghana: A technology threat avoidance theory, Cogent Business \& Management, 7:1.

Abdullah, R. \& Mansor, N. (2015). Forensic Accounting and Fraud Risk Factors: The Influence of Fraud Diamond Theory. The American Journal of Innovative Research and Applied Sciences, 1 (5), 186-192.

Adetayo J.O, Adetayo E.A \& Oladejo B. (2004). Management of Foreign Exchange Risks in a Selected Commercial Bank in Nigeria. Journal of Social Science. 8(3). 207-213.

Allen, F. and Gale, D., 2000, Corporate Governance and Competition, in Xavier Vives (ed.) Corporate Governance: Theoretical and Empirical Perspectives, Cambridge: Cambridge University Press.

Ashu \& Bindu (2009). A study to investigate the reasons for bank frauds and the implementation of preventive security controls in Indian Banking Industry. International Journal of Business Science and Applied Management. Vol 4 Issue 3.

Association of Certified Fraud Examiner (ACFE). (2012). Report to the Nation on occupational Fraud Retrieved June 30th, 2020 from https://acfe.com/documents/2012RttN.pdf

Akinyomi, O. J. (2012). Examination of fraud in the Nigerian banking sector and its prevention. Asian Journal of Management Research, 3(1), $182-194$.

Albrecht, C., Albrecht, W. S. \& Dunn, G. (2001). Can auditors detect fraud? A review of the research evidence. Journal of Forensic Accounting, 2(1), 1-12.

Akindele (2011). Fraud as a Negative Catalyst in the Nigerian Banking Industry, Journal of Emerging Trends in Economics and Management Sciences, 2(5); $357-363$.

Ball, R. (2009). Market and Political/Regulatory Perspective on the recent accounting scandals. Journal of Accounting Research,47(2),277-323.

Banking Fraud Investigations Department, (2010). The report on the statistics and trend of frauds for the year 2012, Central Bank of Kenya.

Charan S. (2016). Frauds in the Indian Banking industry. IIMB Working Pare number 505.

Central Bank of Kenya (2012). Bank Supervision Annual report, 2012, Central Bank of Kenya.

Chiezey, U., \& Onu, A. J. (2013). Impact of Fraud and Fraudulent Practices on the Performance of Banks in Nigeria. British Journal of Arts \& Social Sciences, 15(1).

Cuevas, C. \& Fischer, K. (2006). Cooperative Financial Institutions: Issues in 43

Governance, Regulation and Supervision, World Bank Working Paper No 82.

Cressey D. R. (1973), Other people's money. A study on the social Psychology of

Embezzlement, (New York, USA: Free press 1973).

This publication is licensed under Creative Commons Attribution CC BY.

http://dx.doi.org/10.29322/IJSRP.11.10.2021.p11850

WwW.ijsrp.org 


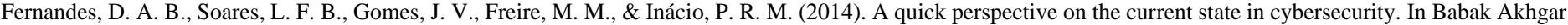
and Hamid R. Arabnia (Eds.), Emerging trends in ICT security (pp. 423-442). Elsevier.

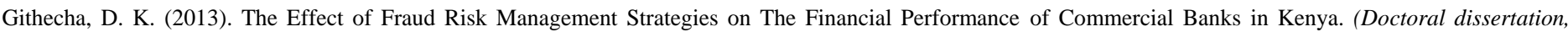
University of Nairobi).

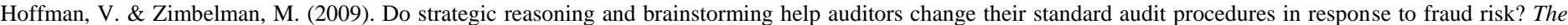
Accounting Review, 84(3), 811-837.

Idolor, J. (2010). Bank Frauds in Nigeria: Underlying causes, effects and possible remedies;

Idowu, A. (2009). An Assessment of Fraud and its management in Nigeria Commercial Banks. European Journal of Social Science, 10(4)

Hirschi, T. \& Gottfredson, M. (1990). Substantive positivism and the idea of crime. Rationality and Society, 2(4), $412-428$.

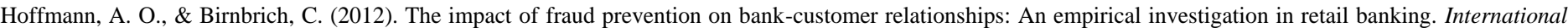
journal of bank marketing, 30(5), 390-407.

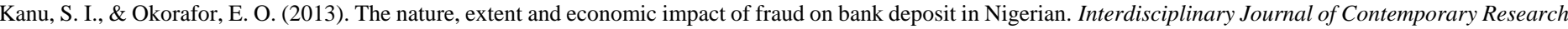
in Business, 4(9), 253-264.

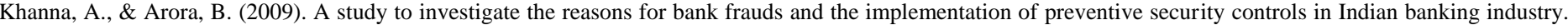
Int. Journal of Business Science and Applied Management, 4(3).

Kimani, J. (2011). Fraud Risk Assessment plan for Barclays Bank of Kenya. Tampere

University of Applied Sciences.

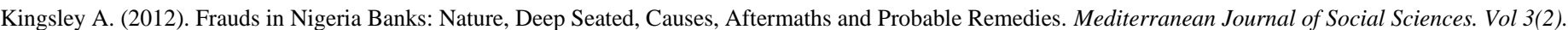

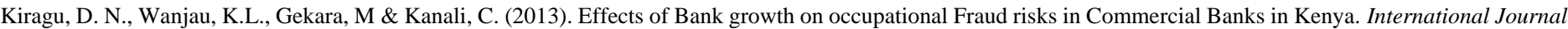
of Social Sciences and Entrepreneurship., I (3), 469-480.

Kothari, C.R. (2004). Research Methodology: Methods \&Techniques (Second Revised Edition), Jaipur Rajasthan, India. New Age International (P) Limited

Lai, F. \& Hsieh, C. (2012). Fighting identity theft: The coping perspective. Decision Support Systems, 52 (2), 353-363

Mahinda, C. G. (2012). Determinants of occupational fraud in commercial banks in Kenya (Doctoral dissertation, University of Nairobi).

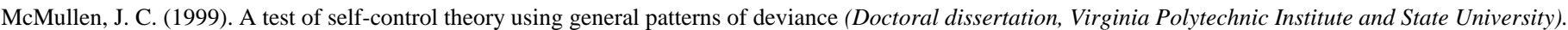

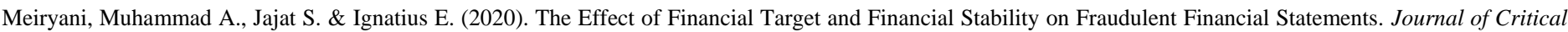
Reviews. Vol 7 Issue 6.

Miller, G. S. (2006). The press as a watchdog for accounting fraud. Journal of Accounting Research, 44(5), 1001-1033.

Mugenda, O. M., \& Mugenda, A. G. (2003). Research Methods. Quantitative and Qualitative approaches, Nairobi, Kenya: Acts Press.

Musoke, P. (2008). REF-BANK FRAUD: A challenge to Uganda's banking industry. Kampala

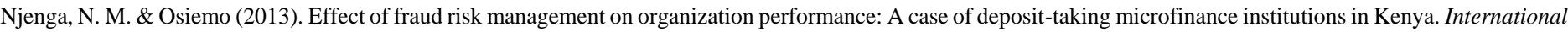
Journal of Social Sciences and Entrepreneurship, 1(7), 490-507.

Nkwankwo O. (2013). Implications of fraud on Commercial Banks Performance in Nigeria. International Journal of Business Management Vol. 8, 2013

Okoye E.I. \& Gbegi D.O (2013). An evaluation of fraud and related crimes on the Nigerian

Economy. An Arabian Journal of Business Management Review, 2013.

Owolabi, S.A. (2010). Fraud and fraudulent practices in Nigeria banking industry. Babcock Journal of Management and social sciences 8(1\&2), 283-298.

Wolfe D. T. \& Hermanson D.R. (2004), The Fraud Diamond: Considering the Four

Elements of Fraud, the CPA Journal December

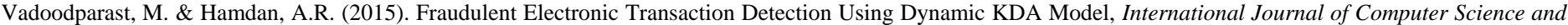
Information Security, 13(3): 90.

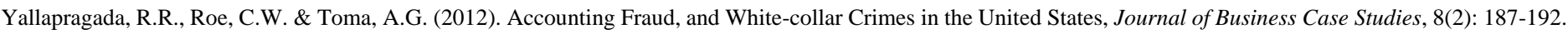

This publication is licensed under Creative Commons Attribution CC BY.

http://dx.doi.org/10.29322/IJSRP.11.10.2021.p11850

wWw.ijsrp.org 
International Journal of Scientific and Research Publications, Volume 11, Issue 10, October 2021 